\title{
DEVELOPMENT OF PROTECTION AGAINST CORONAVIRUS INDUCED DISEASES
}

\section{A Review}

\author{
Luis Enjuanes, ${ }^{1}$ Cristian Smerdou, ${ }^{1}$ Joaquín Castilla, ${ }^{1}$ Inés M. Antón, ${ }^{1}$ \\ Juan M. Torres, ${ }^{1}$ Isabel Sola, ${ }^{1}$ José Golvano, ${ }^{2}$ Jose M. Sánchez, ${ }^{1}$ and \\ Belén Pintado' \\ ${ }^{1}$ Department of Molecular and Cellular Biology \\ Centro Nacional de Biotecnología, CSIC \\ Campus Universidad Autónoma \\ Cantoblanco, 28049 Madrid, Spain \\ ${ }^{2}$ Universidad de Navarra \\ Facultad de Medicina \\ 31080 Pamplona, Spain
}

\section{INTRODUCTION}

Current coronavirus vaccines are classical vaccines, i. e., are based on live attenuated coronavirus. These vaccines provide protection against certain strains of infectious bronchitis virus (IBV) and mouse hepatitis virus (MHV), and with variable results against bovine coronavirus (BCV) and transmissible gastroenteritis virus (TGEV).

Chicken immunized with whole inactivated IBV were protected against virulent challenge ${ }^{15}$. In contrast, chicken immunized with the purified spike (S) glycoprotein, nucleoprotein $(\mathrm{N})$, or membrane $(\mathrm{M})$ proteins did not induce protection ${ }^{17}$. Immunization with the S1 glycoprotein prevented replication of nephropathogenic IBV in kidney, but not in trachea of immunized chicken ${ }^{36}$. Protection did not correlate with the presence of virus neutralizing $(\mathrm{VN})$ and haemagglutination inhibiting $(\mathrm{HI})$ antibodies.

In feline infectious peritonitis virus (FIPV), humoral immunity to $\mathrm{S}$ protein is not protective, and cell mediated immune responses may be important in immunity ${ }^{66}$. The development of a safe and effective vaccine against FIPV has been very problematic. A variety of approaches have been unsuccessful, including the administration of inactivated FIPV, avirulent FIPV or sublethal doses of virulent FIPV, heterologous live virus vaccines [canine coronavirus (CCV), human coronavirus (HCV)-229E, and TGEV], and a recombinant vaccinia virus expressing FIPV S protein ${ }^{98,66}$. Most recently, a temperature-sensitive mutant of FIPV has been developed as an FIPV vaccine. Unfortunately, while testing by the 
manufacturer provided $78 \%$ protection, independent testing gave from 0 to $50 \%$ protection, depending on the strain and dose exposure ${ }^{78}$.

Lactogenic immunity is of primary importance in providing newborn piglets immediate protection against TGEV infection. Effective immunity has only been provided by the administration of virulent virus. Unfortunately, in this case the virus will become enzootic in the farm, preventing its use. Licensed TGEV vaccines have met limited success ${ }^{74,26}, \mathrm{CCV}$ and $\mathrm{BCV}$ vaccines provide partial protection and have to be improved. In summary, effective protection only to two coronaviruses can be elicited using current vaccines, implying the need of a new vaccine design.

\section{Targets in Protection}

The role in protection of the different viral proteins has a variable support. While there are many reports indicating that the $\mathrm{S}$ protein elicits protection against coronaviruses of different species ${ }^{29,17,58,43}$ the role of $\mathrm{M}$ protein, and particularly of the $\mathrm{N}$ protein, is less obvious. There is very little information on the role in protection of the small membrane $(\mathrm{sM})$ protein $^{29}, 17,58,43,31$, and of the non-structural proteins. Proteins exposed in virus or in virus infected cells have a higher probability of being involved in protection. Therefore, it is of interest to identify them.

$\mathrm{S}$ and $\mathrm{M}$ proteins have been detected on the surface of infected cells and these proteins

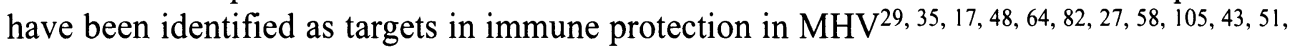
$70,32,89,31,20,44,102,34$. S protein also induces protection against IBV and MHV. These proteins are frequently detected in small quantities in the surface of virus infected cells associated to the presence of virions, while they are detected in the cytoplasm of infected cells in large quantities $^{29,35,17,48,64,82,27,58,105,43,51,70,32,89,31,20,44,102,34}$. These data are in agreement with the concept that coronaviruses assemble at rough endoplasmic reticulum and Golgi membranes. Consequently, most viral proteins are transported through intracellular compartments and only a small proportion, which is not incorporated into virions, is transported to the plasma membrane ${ }^{86}$. Expression of recombinant S, M, sM, haemagglutinin-esterase (HE), and hydrophobic (HP) proteins using poxvirus ${ }^{83}$, 98, 97, 44, adenovirus ${ }^{83,98,97,108,44}$, or baculovirus $105,67,32,106,107,31,108$ has shown that these proteins are found in small amounts on the surface of transformed cells, in the absence of other coronavirus components ${ }^{105}$.This result does not necessarily reflect the situation after coronavirus infection, in which, as mentioned above, viral proteins are mainly found associated to virus bound to cell membranes.

$\mathrm{M}$ protein induces complement-dependent ${ }^{48,} 104$ and possibly complement-independent neutralizing antibodies ${ }^{101,27}$ in assays performed in vitro. The antibodies elicited in vivo failed to protect against MHV challenge in some cases ${ }^{102}$ but not in others ${ }^{27}$. According to the current topological model of coronavirus $\mathrm{M}$ protein, only the amino-terminus of the $M$ protein is exposed on the virus surface $2,9,47,50,38$. In contrast, presented data support that the carboxy-terminus domain of $\mathrm{M}$ protein is exposed on the external virus surface both in TGEV and in $\mathrm{MHV}^{90,72}$ providing a new target for virus or virus-infected cells clearance.

The role of $\mathrm{N}$ protein in protection is being understood ${ }^{102}$. Antibodies to $\mathrm{N}$ protein have no virus neutralizing activity in vitro. An $\mathrm{N}$ protein fragment has been detected in the surface of infected cells (S. Stohlman, personal communication), and it has been shown that a monoclonal antibody (MAb) to the $\mathrm{N}$ protein prevented the cytopathic effect of MHV in $\mathrm{L} \mathrm{cell}^{52}$. This antibody, as well as another non-neutralizing MAb, protected mice from acute disease $^{52}$. In contrast, other anti-N protein antibodies did not provide in vivo protection ${ }^{33}$, $13,88,52$. The mechanism by which the $\mathrm{N}$ protein protects is unclear. It may involve a cell-mediated defense mechanism, e.g. cytotoxic T lymphocyte (CTL) activity ${ }^{85}$,T helper cells ${ }^{103}$, or T cell-derived antiviral cytokines ${ }^{102}$. N-reactive helper $\mathrm{T}$ cells supporting virus- 
specific B cell responses have been demonstrated in $\mathrm{TGEV}^{1}$. This type of response might account for the enhancement of protection observed in MHV after combined immunization with the $\mathrm{N}$ and $\mathrm{S}$ proteins ${ }^{102}$.

HE protein is also exposed on the surface of both BCV particles and infected cells ${ }^{108}$. $\mathrm{HE}$ expressed using recombinant Ad5 induced haemagglutination. Small membrane protein, an integral membrane protein of TGEV having Cexo-Nendo orientation is exposed on the surface of virions. The protein is also exposed on the surface of virus infected cells or insect cells transformed with baculovirus coding for $\mathrm{sM}^{31}$. The $9 \mathrm{kDa}$ HP protein encoded by TGEV ORF7, or the equivalent protein of FIPV ${ }^{21}$ is another accessible membrane-associated protein. The cellular location of HP suggests that it may play a role in the membrane association of replication complexes or in virus assembly ${ }^{92}$.

In summary, there is clear evidence that $\mathrm{S}, \mathrm{M}, \mathrm{HE}, \mathrm{sM}$, and $\mathrm{HP}$ proteins are exposed on the surface of virus infected cells, mostly virion associated, while there is limited evidence on the exposure of $\mathrm{N}$ protein. Nevertheless, all these proteins constitute targets in protection against coronaviruses induced diseases.

\section{B and T Cell Epitopes Involved in Protection}

Antigenic sites in the major structural coronavirus proteins, S, M, N, and HE have been previously described ${ }^{82}$. Extensive studies on $\mathrm{B}$ cell epitopes have been done on the $\mathrm{S}$ protein of MHV, TGEV, IBV, FIPV, and $\mathrm{BCV}^{13}, 86,23,25,59,19,18,30,53,92,20$. The location of antigenic sites inducing virus neutralizing antibodies has been summarized for TGEV, MHV, BCV, and IBV (Figure 1). Most of the information known on FIPV is coincident with that of TGEV ${ }^{75}$. Several S protein antigenic sites have been involved in neutralization: 3 in TGEV, 8 in MHV, 2 in BCV, and 3 in IBV. Most antigenic sites are located on the amino-terminal

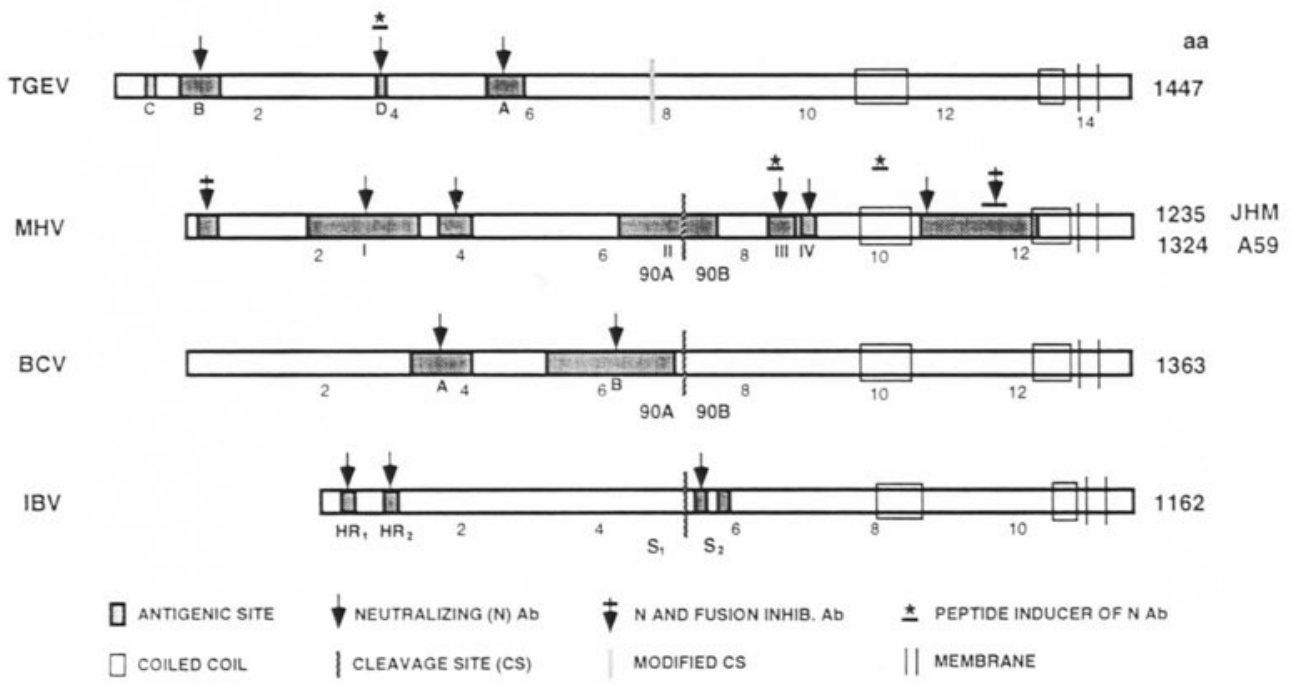

Figure 1. Antigenic sites on aligned coronavirus peplomer protein sequences. The location of dominant antigenic sites (dark squares), of antigenic sites recognized by neutralizing antibodies (arrows) and fusion inhibiting antibodies (arrows with plus sign), and of peptides eliciting protection (lines with star) is shown approximately to scale (small numbers below bars indicate amino acid number in hundreds). TGEV, capital letters below bar indicate the names of the antigenic sites ${ }^{24,30}$. MHV, roman numbers indicate names of defined antigenic sites ${ }^{59,58,73,99,20,91}$. BCV, capital letters below bar indicate defined antigenic sites ${ }^{107}$. IBV, $\mathrm{HR}_{1}$ and $\mathrm{HR}_{2}$ indicate the location of hypervariable regions ${ }^{16,54}$. 
half domain of S protein. TGEV, MHV, and IBV have sites inducing neutralizing antibodies in the first 150 amino acids of S protein. Other sites inducing neutralizing antibodies on the amino-terminal half of S protein are approximately located between amino acids (aa) 200 and 400 (TGEV, MHV, BCV) and between aa 500 and 700 (TGEV, MHV, and BCV) (see Figure 1 for a more precise location). In the S2 half of IBV a site involved in neutralization has been defined next to the right of the trypsin cleavage site. In the S2 half of MHV two domains have been involved in virus neutralization. One contains several epitopes located between aa 800 to 900 , and the other one is located between amino acids 1000 to 1220 . Generally, monoclonal antibodies specific for S1 are more neutralizing than those S2 specific $^{83}$. No antigenic site critical in TGEV neutralization has been identified in the stem portion of TGEV S protein.

Two hypervariable regions identified in IBV S protein at amino acid positions 38-51 and 99-115 from the $\mathrm{N}$-terminus (excluding the signal sequence) are involved in the induction of neutralizing antibodies ${ }^{61}, 43$. In MHV a 13-mer synthetic peptide derived from $S$ protein (aa 846 to 858 ) coupled to an influenza virus T-cell epitope protects against lethal MHV infection ${ }^{43,12}$. A second peptide of 10-mer (aa 993 to 1002) of S protein, coupled to $\mathrm{KLH}$ elicited neutralizing antibodies and a protective immune response in BALB/c mice ${ }^{87}$. One MHV neutralizing MAb which selected escaping mutants with changes at amino acids 255 and 1116, also inhibited fusion activity ${ }^{65,41}$. The information accumulated on the antigenic and functional structure of $\mathrm{S}$ protein in all coronaviruses, indicates that it has a complex three-dimensional structure in native state with interactions between distant domains in the primary structure ${ }^{48,30,20,41}$. S protein fragments extended from the amino terminus, provided recombinant antigens inducing TGEV neutralizing antibodies ${ }^{76}$.

Universal coronavirus vaccines based on a conserved domain of 124 aa found in the $\mathrm{C}$ terminal portions of TGEV, CCV, and FCV S protein have been patented. The report claims that this fragment is capable of eliciting a protective immune response against FIPV, FECV, $\mathrm{TGEV}, \mathrm{BCV}, \mathrm{HCV}$, and $\mathrm{IBV}^{81}$. Further work is required to confirm these findings.

Less information is available on T-cell epitopes (Figure 2). In MHV virus-specific $\mathrm{MHC}$ class II-restricted cytotoxic $\mathrm{CD}^{+}$cells recognize an immunodominant epitope com-

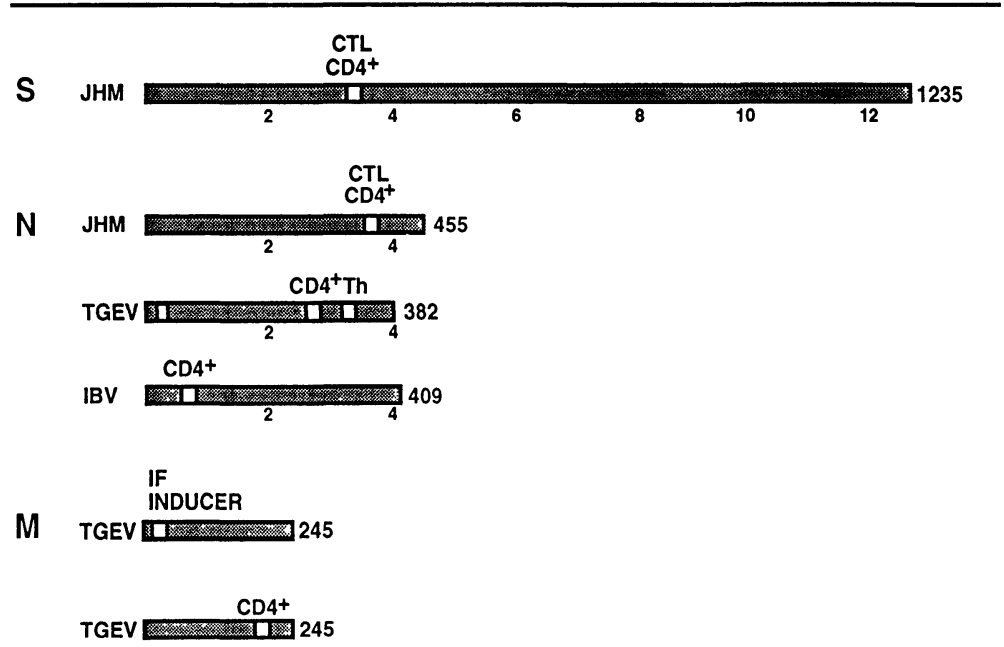

Figure 2. T cell epitopes precisely located in coronavirus proteins. The approximate location of $\mathrm{T}$ cell epitopes on the $\mathrm{S}, \mathrm{N}$, and $\mathrm{M}$ proteins is indicated by white boxes. IF, interferon inducer epitope; CTL, Cytotoxic T cell determinant; Th, T helper cell epitope $\mathrm{e}^{45,7,8,49,1,34,100}$. 
prising the amino acids $329-343$ of the viral S-glycoprotein. The epitope is recognized by polyclonal and virus specific cytotoxic T cell clones ${ }^{34}$. No evidence for the activation of the classical CD8 ${ }^{+}$MHC class I-restricted CTL was found by these authors. MHV-JHM immune $\mathrm{CD}^{+} \mathrm{Th} 1 \mathrm{~T}$ cells transferred to MHV-JHM lethally infected mice results in protection from death, but provides little or no protection from demyelination ${ }^{45}$. CD8 ${ }^{+}$cytotoxic $\mathrm{T}$ cells specific for MHV-JHM are involved in clearance of virus from CNS and thereby provide specific immunological protection. These CTL are specific for both $\mathrm{S}$ and $\mathrm{N}$ protein, but not for $\mathrm{M}$ or $\mathrm{HE}$ proteins. A subset of $\mathrm{CD}^{+}$cells is also involved in virus clearance (S. Stohlman, personal communication). Most (15 out of 20) cell lines established from the brains of infected animals were specific for the $\mathrm{N}$ protein ${ }^{45,84}$. MHV-JHM infection of rats induced immunodominant $\mathrm{CD}^{+}$T-cells which recognized with high prevalence amino acids 388 to 563 of the carboxy-terminal domain of $\mathrm{N}$ protein. The same results were obtained from rats immunized with bacterially expressed $\mathrm{N}$-protein or from animals vaccinated with a stable $\mathrm{N}$-protein expressing vaccinia recombinant. Transfer of $\mathrm{N}$ specific $\mathrm{CD}^{+}{ }^{+} \mathrm{T}$-cells to MHV$\mathrm{JHM}$ infected rats mediated protection against acute disease $\mathrm{e}^{100}$.

$\mathrm{T}$ cell responses to the three major TGEV structural proteins: $\mathrm{S}, \mathrm{M}$, and $\mathrm{N}$ have been identified in haplotype defined TGEV immune miniswine ${ }^{1}$. Four immunodominant $\mathrm{T}$ cell epitopes were identified using 15-mer synthetic peptides, three located in the nucleoprotein (N46, aa 46 to 60 ; N272, aa 272 to 286; and N321, aa 321 to 335) and one on the membrane protein (M196, aa 196 to 210). T lymphocytes from N321 peptide-immune miniswine reconstituted the in vitro synthesis of TGEV-specific antibodies by CD4- TGEV-immune B cells. The antibodies synthesized were directed at least against all three major structural proteins and neutralized TGEV infectivity, indicating that $\mathrm{N} 321$ peptide defines a functional $\mathrm{T}$ helper epitope which elicits $\mathrm{T}$ cells capable of collaborating with $\mathrm{B}$ cells specific for different proteins of TGEV. An interesting epitope has been defined on the M protein of TGEV which induces interferon in naive lymphocytes, and may be relevant in protection ${ }^{49}$.

In IBV, protection is induced by generating cytotoxic and helper T cell responses that augment the activity of $\mathrm{B}$ cells, in producing virus neutralizing antibody. MHC class II-restricted $\mathrm{CD}^{+} \mathrm{T}$-cell hybridomas responded to IBV N protein amino acid sequence 71 to $78^{6,8}$. In summary, $\mathrm{N}$ protein seems to be a dominant antigen for $\mathrm{T}$ cell responses, although $\mathrm{S}$ and $\mathrm{M}$ proteins are also targets for cellular immunity.

\section{Recombinant Vaccines to Protect against Coronavirus}

Vaccinia virus (VV) recombinants expressing coronavirus proteins have been successfully used in preventing MHV induced disease, but not in diseases induced by other coronaviruses as FIPV or TGEV. A strong protection against acute encephalomyelitis was mediated in Lewis rats which were immunized with recombinant VV expressing a fusogenic S-protein ${ }^{28}$. By contrast, a VV recombinant encoding a non fusogenic S-protein variant or the $\mathrm{N}$-protein was not capable to confer protection. In addition, MHV-JHM S-specific IgG antibodies elicited before MHV-JHM challenge modulated the disease process, changing it from an acute disease to subacute demyelinating encephalomyelitis. Immunization with recombinant VV expressing spike (S) protein of FIPV or CCV, induced early death syndrome $(E D S)^{98}$. The epitope responsible for EDS in CCV is found on the first 700 amino-acids of the $\mathrm{S}$ protein.

Empty parvovirus capsids expressing linear epitopes of MHV have also been used to protect against MHV infections. The MHV protective epitope designated site A of strain A59 S protein ${ }^{54}$ was inserted in the major structural protein (VP2) of human parvovirus and expressed using baculoviruses ${ }^{12}$. The peptide (H2N-846-SPLLGCIGSTCAE-858-COOH) has 13 amino acids. The $58 \mathrm{kDa}$ protein assembled into capsids resembling native $\mathrm{B} 19$ virion, when expressed in insect cells. Immunoelectron microscopy indicated that the epitopes 
inserted in the loop were exposed on the surface of the chimeric particles. Antibodies specific for the inserted sequences were induced, which recognized the native virus. Mice immunized with the chimeric capsids were partially protected against a lethal challenge infection with MHV. It will be interesting to determine whether expression of linear epitopes from other coronavirus will also provide protection against the homologous virus.

\section{Vectors to Induce Mucosal Immunity}

Coronavirus often infect respiratory or enteric mucosal areas. Then, a strategy that could elicit protection against coronavirus infections is the induction of mucosal immunity. Extensive studies that span more than 20 years from many laboratories have shown that the precursor for mucosal IgA plasma cells originate in the lymphoepithelial structures in the gastrointestinal and respiratory tracts. This precursor, which switch or commits to IgA in gut, or bronchus-associated lymphoepithelial tissues (BALT) migrate from gut associated lymphoid tissues (GALT) to mesenteric lymph nodes, upper respiratory tracts or to exocrine tissues such as the mammary gland, where terminal differentiation into IgA secreting plasma cells takes place. Prokaryotic and eukaryotic vectors with tropism for GALT have been used to elicit immune response to coronavirus.

Human and bovine enteropathogenic strains of Escherichia coli have a multimeric surface protein CS31A that has been used as a carrier for foreign antigenic determinants ${ }^{10}$. Site D (named site C by H. Laude's group) of TGEV S protein includes a continuous epitope which can be represented by a synthetic peptide able to induce virus neutralizing antibodies ${ }^{69,30}$. Sequences coding for antigenic site $\mathrm{D}^{69,30,68}$ have been cloned in the V3 region of CS31A protein. The recombinant hybrid protein was purified and used to immunize mice with $20 \mu \mathrm{g}$ of antigen per dose. Significant antibody titers and neutralization of the virus was demonstrated. In contrast, antibody titers to TGEV induced by the recombinant bacteria were $l^{10}{ }^{10}$. Site D from TGEV S protein fused to $E$. coli heat-labile toxin B (LT-B) subunit was expressed in attenuated Salmonella providing a collection of 6 recombinant antigens with a variable number of site $\mathrm{D}^{80}$. LT-B-site D fusion products were purified and subcutaneously inoculated into rabbits, in order to determine their immunogenicity. One of the hybrid proteins induced TGEV neutralizing antibodies. The corresponding plasmid was used to transform the vaccine strain $S$. typhimurium $\Delta$ cya $\Delta$ crp $\Delta$ asd $\chi 3987$. Constitutive expression of LT-B-site D protein led to the selection of bacteria expressing a recombinant product that formed pentamers and showed high stability in vitro. The recombinant bacteria also elicited TGEV specific antibodies in $v i v o^{80}$. Expression of TGEV S protein in avirulent $S$. typhimurium yield recombinant antigens with variable toxicity in bacteria. Transformed bacteria expressing a $53 \mathrm{kDa}$ amino-terminal fragment of the $\mathrm{S}$ protein and the whole protein $(144 \mathrm{kDa})$, respectively, showed an acceptable stability. Recombinant bacteria expressing the aminoterminal fragment of S protein was selected as a potential bivalent vector to induce both immunity to Salmonella and to TGEV. The bacteria colonized swine and induced an antibody response to Salmonella, but the response against TGEV was weak. Prokaryotic vectors developed so far, do not seem the ideal candidates to induce protective immunity against coronaviruses, possible because $\mathrm{S}$ protein is an essential antigen in protection against coronaviruses, and the conformation of this antigen is highly dependent on glycosylation $^{23,19}$.

Among the eukaryotic vectors with tropism for GALT or BALT, adenoviruses are nowadays widely used. Two types of adenovirus vectors have been developed: non-defective (vectors with substitutions in E3) which can replicate in many permissive cells, and induce high level expression of the foreign insert, and defective vectors (with E1 gene deleted) which only replicate in 293 cells that provide E1 gene functions in trans. Non-defective and 
defective adenovirus vectors allow the expression of heterologous genes with up to 4,5 and $8 \mathrm{~kb}$, respectively. These vectors are highly stable and induce strong responses ${ }^{5,76}$.

MHV S, N, and M proteins have been expressed using human adenovirus serotype 5 (Ad5). Mice intraperitoneally inoculated with these recombinants elicited serum antibodies which specifically recognized the respective proteins. Only antibodies to S protein neutralized MHV in vitro, but titers were low. $\mathrm{N}$ protein also induced detectable antibodies as determined by ELISA. By contrast, upon intracerebral challenge with a lethal dose of MHV, a significant fraction of animals vaccinated with adenovirus vectors expressing either the $S$ or the $\mathrm{N}$ protein were protected. This protective effect was significantly stronger when the animals were immunized with recombinants expressing both $\mathrm{S}$ and $\mathrm{N}$ protein, as compared to survival after single immunizations ${ }^{102}$.

TGEV spike protein has been expressed using Ad5. The whole protein, or fragments of different lengths: 378, 529, and 1109 amino acids extended from the amino-terminus have been expressed. The recombinant antigens included different sets of the antigenic sites $C$, B, D, and A, previously defined in the TGEV S protein ${ }^{76}$. These Ad5-TGEV-S recombinants infect hamsters and swine ${ }^{91}$, and induce TGEV neutralizing antibodies. Furthermore, Ad5TGEV-S immune hamsters secrete TGEV neutralizing antibodies in the milk during lactation $^{76}$, indicating that these recombinants might have a potential in protection against enteric diseases caused by coronaviruses. Vectors based on porcine adenoviruses are being developed $^{62,71}$.

HE of BCV has been expressed using Ad5. The recombinant HE polypeptide existed in monomeric $(65 \mathrm{~K})$ and dimeric form $(130 \mathrm{k})$. Mice inoculated intraperitoneally with live recombinant Ad5-HE elicited a significant level of BCV-neutralizing antibodies ${ }^{108}$. Protection experiments are being performed with live recombinant virus.

\section{Development of Coronavirus Based Vectors}

To immunize a determined animal species against a coronavirus it might be advisable to use a vector based on coronaviruses isolated from the corresponding specie. This would provide several advantages: i) The coronavirus is a multiantigenic system which could elicit a polyvalent immune response that may prevent the appearance of escaping mutants; ii) virus vectors can be selected with a tropism identical to the one exhibited by virulent wild type (wt )virus, inducing a local immune response where required; and, iii) vector approval for use in a given species by regulatory agencies may be easier when vaccines are derived from viruses affecting the same species. Then, it may be convenient to develop vectors based in coronaviruses. The ultimate goal is to develop a replication competent coronavirus RNA vector (Figure 3, C). From this, safer vectors could be derived by introducing a deletion removing an essential virus protein, which could be provided in trans by a packaging cell line (Figure 3, C). Also suicide vectors could be derived by deleting the encapsidation signal from the helper virus. Unfortunately, the coronavirus genome (around $30 \mathrm{~kb}$ ) is too large to be cloned and expressed as a single infectious RNA for technical reasons. The construction of these vectors is based on genetic manipulation of single-strand positive-sense RNA genomes, which today can be done by recombination between $w t$ genomes and genetically engineered defective interfering (DI) RNAs of small size.

At least two types of vectors based on coronaviruses can be anticipated as intermediate steps towards the construction of a non-defective coronavirus vector: i) a helper-dependent RNA-replication defective virion, which requires the cooperation of a helper virus for its replication (Figure 3, A); ii) a helper independent (replicase +) defective virus, capable of self replicating the RNA, but dependent for assembly on structural proteins provided in trans by a second RNA molecule derived from a DI genome (Figure 3, B). The replicase, as defined today, is coded by a $20 \mathrm{~kb}$ fragment, which makes difficult the construction of an 


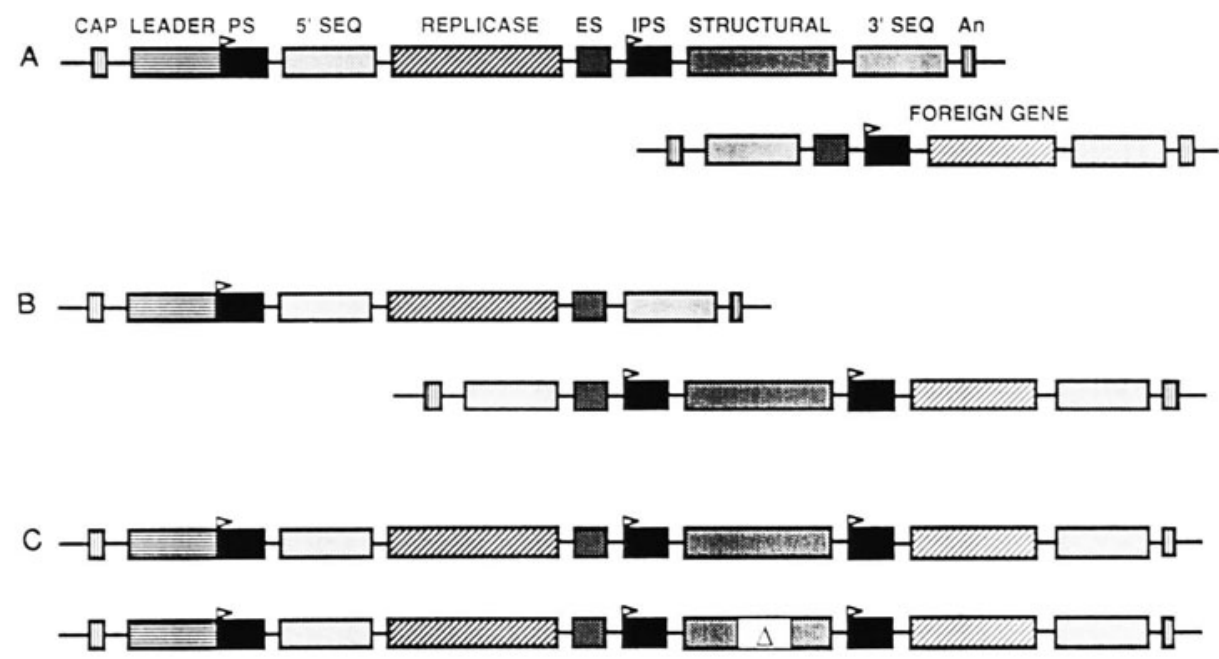

Figure 3. Models of potential coronavirus-derived expression constructs. A. Summarized structure of helper virus (upper part) and a DI genome engineered as a vector to express foreign genes (lower bar). B. Structure of a potential coronavirus based replicon (upper bar) and an engineered DI carrying information to code for structural proteins and foreign antigens (lower construct). C. Single RNA genome with the information for the replicase, essential proteins, and heterologous genes (upper bar). A defective genome can be derived by the introduction of a deletion $(\Delta)$ in an essential gene (lower bar). PS, promoter sequences; ES, encapsidation signal; IPS, internal promoter sequences; An, poly A. Triangles above bars indicate promoter position.

RNA replicon, to be expressed from a DNA vector, as shown for nodavirus, alphaviruses, and other small RNA viruses ${ }^{56,11,4}$. These vectors are safer, but their immunogenicity usually is lower than that of vectors which replicate and encapsidate. These vectors could be passaged several times before their ability to replicate is lost. The replication is maintained as far as both the replicon containing RNA and the RNA coding for structural proteins are passed together.

Key contributions to progress in this area have been the studies on the minimum cis-signal requirements for DI RNA replication ${ }^{61,60,93,39}$. Most advanced work is coming from laboratories dealing with MHV. An MHV DI RNA-based expression system (Figure 4A) ${ }^{57}$ represents one of the first MHV-based expression vectors derived from a coronavirus. This vector has low packaging efficiency, although it includes the packaging signal described so far.

Expression in these vectors relies on an internal ribosome entry site (IRES) before the heterologous gene (Figure 4A), or on the transcription of a subgenomic RNA by introducing a coronavirus derived internal promoter sequence (IPS) at the $5^{\prime}$ end of the heterologous gene (Figure 4B). Chloramphenicol acetyltransferase (CAT), luciferase, and MHV hemagglutinin-esterase HE proteins have been expressed using this type of vectors (Figure $4 \mathrm{~B})^{55}$. Both the wild-type and recombinant HE proteins are incorporated into viral particles, thus generating a pseudo-recombinant virus. The recombinant DI RNA can be passaged at least four times. This DI RNA is thus an effective expression vector for delivering foreign genes into virus-infected cells. Another RNA vector based on MHV DI particles has been obtained (Figure 4C) ${ }^{94}$. Studies on the replication of this vector have revealed that the MHV DI RNAs require a functional open reading frame (ORF) for efficient propagation ${ }^{22}$. The DI-vector could be used to modify the helper virus genome by homologous recombination to express heterologous genes. Site directed recombination has been shown between full length RNA genomes containing a ts mutation on the N gene, and a DI RNA genome, 
Figure 4. Coronavirus derived expression constructs. A. Structure of a MHV DI genome used as a vector to express a foreign gene (CAT) using an IRES ${ }^{57}$. B. DI genome engineered to express a heterologous gene (HE) under the control of an internal promoter sequence (IPS) ${ }^{55}$. C. Recombination between a helper virus and a MHV DI genome (MIDI-C) to modify $\mathrm{N}$ protein of helper virus. This technique can be used to introduce foreign genes that could be expressed by coro-

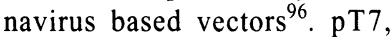
phage T7 promoter, ES, encapsidation signal; IRES, internal ribosome entry site; CAT, chloramphenicol acetyl transferase reporter gene; IPS, internal promoter sequence; HE, haemagglutinin-esterase; $\mathrm{N}, \mathrm{N}$ protein; $t s$, temperature sensitive mutation.

containing a $w t \mathrm{~N}$ gene ${ }^{40}$. The frequency of site directed homologous recombination was significantly increased with the use of encapsidated co-replicating RNAs ${ }^{96}$.

The aims are directed to the development of a system which obviates the need of a helper virus. A vector containing the gene encoding the RNA dependent RNA polymerase, and the replication signals will be required. Mapping the replication signals and polymerase gene reconstruction are priority goals. Such a vector can only be rescued into virus particles in the presence of the structural proteins. Assembly of DI particles in the absence of helper virus using transient expression of the structural proteins $\mathrm{S}, \mathrm{M}, \mathrm{N}$, and $\mathrm{sM}$, and the synthetic DI RNA has been achieved (W. Spaan, personal communication).

Optimization of the expression in coronavirus requires information on transcription regulation, which nowadays is under debate. The extent of base pairing between the promoter and the leader complementary promoter sequence has been proposed as the control of subgenomic RNA abundance ${ }^{82,46}$. In fact, certain nucleotide substitutions in the $3^{\prime}$ consensus sequence impair promoter activity. However, other data from MHV, IBV, and FIPV indicates that there is no correlation between potential base pairing and mRNA abundance ${ }^{42,95}$. Mutations disrupting the RNA duplex do not reduce promoter activity more than conservative substitutions in the same position ${ }^{95}$. One interpretation of all the data is that successful transcription initiation requires a promoter-leader duplex of minimal stability. Once this condition is met, extending the base pairing does not increase the rate of transcription initiation ${ }^{95}$.

Coronavirus mRNAs are synthesized in MHV infected cells at a rate inversely related to their length ${ }^{79}$. In contrast, in FIPV and TGEV infected cells the shortest mRNAs (RNAs 7 and 6, respectively) are produced in much smaller quantities than the next larger mRNAs encoding the nucleocapsid protein. These data suggest that vectors based on different coronaviruses will have to use various promoters for optimum expression. Fusion of leader and body is imprecise. To explain the generation of this heterogeneity it has been proposed that leader RNAs are trimmed by a nuclease to remove the single-stranded RNA sequence from the $3^{\prime}$ end after the leader complementary promoter sequence is annealed to the promoter $^{3}$. Alternatively, it has been proposed ${ }^{37}$ that a sequence-specific nuclease cleaves the leader RNA at position 1 or 2 of the consensus sequence. More recently it has been proposed $^{95}$ that transcription is initiated at multiple, possibly random, sites within the IPS. A $3^{\prime}$ to $5^{\prime}$ nuclease activity present in many RNA polymerases could remove $3^{\prime}$ residues in the IPS causing the heterogeneity. 


\section{Resistance to Virus Infections: Intracellular Interference and Transgenic Animals}

Two strategies in the construction of transgenic animals resistant to viral infection could be distinguished: i) "intracellular immunity", which could have been more appropriately named intracellular interference, and ii) development of transgenic animals providing immunoprotection. Intracellular interference includes: i) anti-sense RNA and ribozyme approaches; ii) trans-dominant negative mutant viral proteins; iii) molecular decoys; and, iv) intracellular expression of antibody to viral proteins. Antisense oligonucleotides containing sequences complementary to leader RNA induced a significant effect on the multiplication of MHV-JHM. A vector which expressed the antisense mRNA7 of MHV decreased virus multiplication in cell cultures. In transfected cell lines expressing a ribozyme against the $5^{\prime}$ end of MHV genome, MHV-multiplication was inhibited by more than $98 \%$ at $12 \mathrm{~h}$ post infection $^{77}$. Transgenic mice expressing antisense RNA against the nucleocapsid protein gene of MHV, under the control of RSV LTR, were more resistant to the lethal challenge of MHV than non-transgenic mice ${ }^{63}$.

Interference in plant and mammalian viruses is provided by expression of the coat protein or the replicase of a virus in the cells susceptible of infection. Little has been done in coronaviruses in this subject. cDNAs engineered using DI RNAs might be used to study the interference in coronavirus replication, mediated by defective products of different ORFs.

Single-chain antibody molecules specific for surface S glycoprotein of MHV have been constructed to interfere with coronavirus induced diseases ${ }^{41}$. The single chain antibody was derived from a murine MAb that has a high binding affinity and neutralizes virus infectivity. Single chain antibodies have been expressed in CRFK and DBT cells using eukaryotic expression vectors with human cytomegalovirus or metallothionein promoters ${ }^{41}$. The resistance of these cells to virus infection and $\mathrm{S}$ protein-mediated membrane fusion is being evaluated.

Transgenic pigs secreting TGEV neutralizing antibodies in the milk, to passively protect the progeny, are being constructed. The project is based on the protection of newborn animals by oral administration of IgG or IgA antibodies purified from immune sows, previously reported. The genes coding for the light and heavy chain of TGEV neutralizing MAb 6A.C3, which recognizes a conserved epitope of $\mathrm{S}$ protein ${ }^{75}$ have been expressed under the control of the whey acid protein (wap) promoter. This promoter is activated by peptidic and steroid hormones present in stimulating concentration in the mammary gland during lactation. Activation of wap promoter results in the synthesis of WAP protein very abundant in the milk. The recombinant antibody has been expressed under the control of both human cytomegalovirus and wap promoters in cell culture ${ }^{14}$. Recombinant antibody had titers of $10^{4}$ as determined by RIA, and neutralization index of $4 \log$ units, using TGEV antigen or infectious virus, respectively. Transgenic mice carrying the genes coding for both the heavy and light chains of 6A.C3 MAb have been developed. The presence of TGEV specific antibody in the milk of transgenic mice during lactation is being determined. Constructs providing optimum levels of TGEV neutralizing antibody will be used to produce transgenic pigs.

\section{ACKNOWLEDGMENTS}

This work has been supported by grants from the Consejo Superior de Investigaciones Científicas, the Comisión Interministerial de Ciencia y Tecnología, Instituto Nacional de Investigaciones Agrarias, La Consejería de Educación y Cultura de la Comunidad de Madrid, 
and Laboratorios Sobrino (Cyanamid) from Spain, and the European Communities (Projects Science and Biotech)

\section{REFERENCES}

1 Anton, I M, Gonzalez, S, Bullıdo, M J, Suñe, C, Meloen, R H, Borras-Cuesta, F, Enjuanes, L Immunodominant $T$ cell epitopes of transmissible gastroenteritis virus major structural proteins $\mathrm{J}$ Virol 1994 In press

2 Armstrong, J, Niemann, H, Smeekens, S, Rottier, P, Warren, G Sequence and topology of a model intracellular membrane protein Nature 1984, 308 751-752

3 Baker, S C, Lal, M M C An In vitro system for the leader-primed transcription of coronavirus messenger RNAs EMBO J 1990, 9 4173-4179

4 Ball, A L cls-actıng requirements for the replication of flock house virus RNA2 J Virol 1993, 67 3544-3551

5 Bett, A J , Prevec, L , Graham, F L Packagıng capacity and stability of human Adenovirus type 5 vectors J Virol 1993, 67 5911-5921

6 Boots, A M, Van-Lierop, M J, Kusters, J G, Van-Kooten, G J, Van-der-Zeijst, B A, Hensen, E J MHC ClassII-restricted T-cell hybridomas recognızıng the nucleocapsid protein of avian coronavirus IBV Immunology 1991, 72 10-14

7 Boots, A M H, Benaissatrouw, B J, Hesselınk, W, Rijke, E, Schrier, C, Hensen, E J Induction of anti-viral immune responses by immunization with recombinant-DNA encoded avian coronavirus nucleocapsid proteın Vaccine 1992, 10 119-124

8 Boots, A M H, Kusters, J G, Vannoort, J M, Zwaagstra, K A, Rıjke, E, Vanderzeısst, B A M, Hensen, E J Localization of a T-cell epitope within the nucleocapsid protein of avian coronavirus Immunology 1991, 74 8-13

9 Boursnell, M E, Brown, T D K, Binns, M M Sequence of the membrane protein gene from avian coronavirus IBV Virus Res 1984, 1 303-313

10 Bousquet, F, Martın, C, Girardeau, J P, Mechın, M C, Vartanıan, M d CS31A capsule-lıke antıgen as an exposure vector for heterologous antigenic determinants Infec Immun 1994, 62 2553-2561

11 Bredenbeeck, P J , Rice, C M Anımal RNA virus expressıon systems Sem Virol 1992, 3 297-310

12 Brown, C S, Wellıng-Wester, S, Feıjlbrief, M, Van Lent, J W M, Spaan, W J M Chımerıc Parvovırus B19 capsids for the presentation of foreign epitopes Virology 1994, 198 477-488

13 Buchmeier, M J, Lewickı, H A, Talbot, P J, Knobler, R L Murine hepatitis virus-4 (strain JHM)-induced neurologic disease is modulated in vivo by monoclonal antibody Virology 1984, 132 261-270

14 Castilla, J, Sola, I , Pintado, B , Hennighausen, L, Enjuanes, L Expression of immunoglobulin genes in the mammary gland Resistance to virus infection 1994 Fundacion Juan March, Madrid, Spain

15 Cavanagh, D, Davıs, P J, Derbyshıre, J H, Peters, R W Coronavirus IBV virus retaınıng spıke glycopolypeptide S2 but not S1 is unable to induce virus-neutralızing or haemagglutınation-inhibitıng antıbody, or induce chicken tracheal protection J Gen Virol 1986, 67 1435-1442

16 Cavanagh, D , Davis, P J , Mockett, A P Amıno acids withın hypervariable region 1 of avian coronavirus IBV (Massachusetts serotype) spıke glycoproteın are associated with neutralızıng epıtopes Virus Res 1988, $11141-150$

17 Cavanagh, D, Derbyshıre, J H, Davis, P J, Peters, R W Induction of humoral neutralısıng and haemagglutınation-ınhıbitıng antıbody by the spıke protein of avian infectious bronchitıs virus Avian Pathol 1984, 13 573-583

18 Correa, I, Gebauer, F, Bullıdo, M J, Suñe, C, Baay, M F D, Zwaagstra, K A, Posthumus, W P A, Lenstra, J A, Enjuanes, L Localization of antigenic sites of the E2 glycoprotein of transmissible gastroenteritis coronavirus J Gen Virol 1990, 71 271-279

19 Correa, I, Jımenez, G, Suñe, C , Bullıdo, M J , Enjuanes, L Antıgenıc structure of the E2 glycoproteın from transmissible gastroenteritıs coronavirus Virus Res 1988, 10 77-94

20 Daniel, C, Anderson, R, Buchmeıer, M J, Flemıng, J O, Spaan, W J M, Wege, H, Talbot, P J Identification of an immunodominant linear neutralization domain on the S2 portion of the murine coronavirus spike glycoprotein and evidence that it forms part of a complex tridimensional structure $\mathbf{J}$ Virol 1993, 67 1185-1194

21 De Groot, R J , Andeweg, A C , Horzinek, M C, Spaan, W J M Sequence analysis of the 3' end of the feline coronavirus FIPV 79-1146 genome comparison with the genome of porcine coronavirus TGEV reveals large insertions $\mathrm{J}$ Virol 1988, $167 \quad 370-376$ 
22 De Groot, R J, Vandermost, R G, Spaan, W J M The fitness of defective interfering murne coronavirus-DI-a and its derivatives is decreased by nonsense and frameshift mutations J Virol 1992, 66 5898-5905

23 Delmas, B, Gelfi, J, Laude, H Antıgenic structure of transmissible gastroenteritıs virus II Domains in the peplomer glycoprotein J Gen Virol 1986, 67 1405-1418

24 Delmas, B, Rasschaert, D, Godet, M, Gelfi, J, Laude, H Four major antigenic sites of the coronavirus transmissible gastroenteritis virus are located on the amino-terminal half of spike protein J Gen Virol 1990, 71 1313-1323

25 Deregt, D , Babiuck, L A Monoclonal antıbodies to bovine coronavirus characterıstics and topograph1cal mapping of neutralızing epitopes on the E2 and E3 glycoproteins Virology 1987, 68 41-420

26 Enjuanes, L, Van der Zeijst, B A M Molecular basis of transmissible gastroenteritıs coronavirus (TGEV) epidemılogy In Siddell S G, (eds), Coronaviruses Plenum Press, New York 1995 In press

27 Flemıng, J O, Shubın, R A, Sussman, M A, Casteel, N, Stohlman, S A Monoclonal antibodies to the matrix (E1) glycoprotein of mouse hepatitıs virus protect mice from encephalitis Virology 1989, 168 $162-167$

28 Flory, E , Pfleiderer, M, Stuhler, A, Wege, $\mathrm{H}$ Induction of protectıve immunity against coronavirus-induced encephalomyelitıs evidence for an important role of CD8+ T cells in vivo Eur J Immunol 1993, $23 \quad 1757-1761$

29 Garwes, D J, Lucas, M H, Higgins, D A, Pike, B V, Cartwright, S F Antigenicity of structural components from porcine transmissible gastroenteritis virus Vet Microbiol 1978, 3 179-190

30 Gebauer, F, Posthumus, W A P, Correa, I, Suñe, C , Sanchez, C M , Smerdou, C , Lenstra, J A , Meloen, $R$, Enjuanes, $L$ Residues involved in the formation of the antigenic sites of the $S$ protein of transmissible gastroenteritis coronavirus Virology 1991, 183 225-238

31 Godet, M, L'Harıdon, R, Vautherot, J F, Laude, H TGEV coronavirus ORF4 encodes a membrane protein that is incorporated into virions Virology 1992, 188 666-675

32 Godet, M, Rasschaert, D, Laude, $\mathrm{H}$ Processing and antıgenicity of entire and anchor-free spike glycoprotein-S of coronavirus TGEV expressed by recombinant baculovirus Vırology 1991, 185 $732-740$

33 Hasony, H J , MacNaughton, M R Antigenicity of mouse hepatitis virus strain 3 subcomponents in C57 strain mice Arch Virol 1981, 69 33-41

34 Heemskerk, M H M, Schoemaker, H M, Spaan, W J M, Boog, C J P Induction of MHC class II-restricted CD4+ cytotoxic T cells by MHV-A59 European Immunology Meetıng 1994 Barcelona, Spain W29

35 Holmes, K V, Doller, E W, Behnke, J N Analysis of the functions of coronavirus glycoproteıns by differential inhibition of synthesis with tunicamycin Adv Exp Med Biol 1981, 142133

36 Ignatovic, J, McWaters, P G Monoclonal antibodies to three structural proteins of avian infectious bronchitis virus characterization of epitopes and antigenic differentiation of Australian strains $\mathrm{J}$ Gen Virol 1991, 72 2915-2922

37 Joo, M, Makıno, S Mutagenıc analysıs of the coronavırus intergenıc consensus sequence J Vırol 1992, $66 \quad 6330-6337$

38 Kapke, P A, Tung, F Y T, Hogue, B G, Brian, D A, Woods, R D, Wesley, R The amıno-terminal signal peptide on the porcine transmissible gastroenteritis coronavirus matrix protein is not an absolute requirement for membrane translocation and glycosylation Virology 1988, 165 367-376

$39 \mathrm{Kım}, \mathrm{Y} \mathrm{N}$, La1, M M C , Makıno, S Generation and selection of coronavirus defective interferıng RNA with large open reading frame by RNA recombination and possible editing Virology 1993, 194 244-253

40 Koetzner, C A, Parker, M M, Ricard, C S, Sturman, L S, Masters, P S Repair and mutagenesis of the genome of a deletion mutant of the coronavirus mouse hepatitis virus by targeted RNA recombination J Virol 1992, 66 1841-1848

$41 \mathrm{Kolb}, \mathrm{A}$, Grosse, B, Siddell, S G Immunological prevention of coronavirus infection Resistance to viral infection 1994 Fundacion Juan March, Madrid, Spain

42 Konıngs, D A M, Bredenbeek, P J, Noten, J F H , Hogeweg, P, Spaan, W J M Differential premature termination of transcription as a proposed mechanism for the regulation of coronavirus gene expression Nuc Ac Res 1988, 16 10849-10860

43 Koolen, M J M, Borst, M A J, Horzinek, M C, Spaan, W J M Immunogenıc peptıde comprising a mouse hepatitis virus A59 B-cell epitope and an influenza virus T-cell epitope protects against lethal infection J Virol 1990, 64 6270-6273

44 Kubo, H, Taguchi, F Expression of the S1 and S2 subunits of murine coronavirus JHMV spike protein by vaccinia virus transient expression system J Gen Virol 1993, 74 2372-2383 
45 Kyuwa, S, Stohlman, S Advances in the study of MHV infection of mice Adv Exp Med B1ol 1990, $276555-556$

46 Lai, M M C Coronavirus - organization, replication and expression of genome Ann Rev Microbiol 1990, 44 303-333

47 Lapps, W, Hogue, B G, Brian, D A Sequence analysis of the bovine coronavirus nucleocapsid and matrix protein genes Virology 1987, 157 47-57

48 Laude, H, Chapsal, J M, Gelfi, J, Labiau, S, Grosclaude, J Antıgenıc structure of transmissıble gastroenteritıs virus I Properties of monoclonal antıbodies directed against virion proteins $\mathrm{J}$ Gen Virol 1986, 67 119-130

49 Laude, H, Gelfi, J, Lavenant, L, Charley, B Single amıno acid changes in the viral glycoprotein M affect induction of alpha interferon by the coronavirus transmissible gastroenteritıs virus J Virol 1992, 66 743-749

50 Laude, H , Rasschaert, D , Huet, J C Sequence and N-terminal processing of the transmembrane protein E1 of the coronavirus transmissible gastroenteritis virus J Gen Virol 1987, 68 1687-1693

51 Laviada, M D, Videgain, S P, Moreno, L, Alonso, F, Enjuanes, L, Escribano, J M Expression of swine transmissible gastroenteritis virus envelope antigens on the surface of infected cells epitopes externally exposed Vir Res 1990, 16 247-254

52 Lecomte, J, Cainellı-Cebera, V, Mercier, G, Mansour, S, Talbot, P, Lussier, G, Oth, D Protection from mouse hepatitis virus type 3-induced acute disease by an ant1-nucleoprotein monoclonal antibody Arch Virol 1987, 97 123-130

53 Lenstra, J A, Erkens, J H F, Langeveld, J G A, Posthumus, W P A, Meloen, R H, Gebauer, F, Correa, I , Enjuanes, L , Stanley, K K Isolation of sequences from a random-sequence expression library that mimic viral epitopes J Immunol Meth 1992, 152 149-157

54 Lenstra, J A, Kusters, J G, Koch, G, van der Zeıjst, B A M Antıgenıcity of the peplomer protein of infectious bronchitis virus Molec Immunol 1989, 26 7-15

55 Liao, C -L , La1, M M C The requirement of 5'-end genomic sequence as an upstream cis-acting element for coronavirus subgenomic mRNA transcription J Virol 1994, In Press

56 Liljestrom, P, Garoff, H A new generation of anımal cell expression vectors based on the Semlıkı forest virus replicon Biotechnology 1991, 9 1356-1361

57 Lin, Y J , La1, M M C Deletion mapping of a mouse hepatıtıs virus defectıve interfering RNA reveals the requirement of an internal and discontıguous sequence for replication J Virol 1993, 67 6110-6118

58 Luytjes, W, Geerts, D, Posthumus, W, Meloen, R, Spaan, W J M Amıno acid sequence of a conserved neutralızıng epitope of murıne coronaviruses J Virol 1989, 63 1408-1415

59 Makıno, S, Flemıng, J O, Keck, J G, Stohlman, S T, Laı, M M C RNA recombınation of coronaviruses localization of neutralızıng epitopes and neuropathogenic determinants on the carboxyl termınus of peplomers Proc Natl Acad Sc1 1987, 84 6567-6571

60 Makıno, S, Joo, M , Makıno, J K A System for study of coronavirus messenger RNA synthesıs - a regulated, expressed subgenomic defective interferıng RNA results from intergenic site insertion $\mathrm{J}$ Virol 1991,65 6031-6041

61 Makıno, S, Yokomorı, K, La1, M M C Analysıs of efficiently packaged defective interferıng RNAs of murıne coronavirus - localızation of a possible RNA-packaging signal J Virol 1990, 64 6045-6053

62 Mengelıng, W L Porcine coronaviruses co-infection of cell cultures with transmissible gastroenteritıs virus and hemagglutınatıng encephalomyelitıs Am J Vet Res 1973, 34 779-783

63 Mizutanı, T, Hayashı, M, Maeda, A, Sasakı, N, Yamashsıta, T, Kasaı, N, Namıoka, S Inhıbıtıon of mouse hepatitis virus multiplication by antisense oligonucleotıde, antisense RNA, sense RNA, and ribozyme Adv Exp Med Biol 1994, 276 129-135

64 Nakanaga, K, Yamanouchı, K, Fujıwara, K Protectıve effect of monoclonal antıbodies on lethal mouse hepatitis virus infection in mice J Virol 1986, 59 168-171

65 Niesters, H G M, Lenstra, J A, Spaan, W J M, Z1jderveld, A J , Bleumınk-Pluym, N M C, van der Zeijst, B A M The peplomer protein sequence of the M41 strain of coronavirus IBV and its comparison with Beaudette strains Vir Res 1986, 5 253-263

66 Olsen, C W A review of feline infectious peritonitıs virus molecular biology, immunopathogenesis, clinical aspects, and vaccination Vet Microbiol 1993, 36 1-37

67 Parker, M M , Masters, P S Sequence comparıson of the N genes of five strains of the coronavirus mouse hepatitis virus suggests a three domain structure for the nucleocapsid protein Virology 1990, 179 463-468

68 Posthumus, W P A, Lenstra, J A, van Nieuwstadt, A P, Schaaper, W M M , van der Zeijst, B A M , Meloen, R H Immunogenicity of peptıdes simulatıng a neutralızıng epitope of transmissible gastroenteritis virus Virology 1991, 182 371-375 
69 Posthumus, W P A, Meloen, R H, Enjuanes, L, Correa, I, van Nieuwestadt, A, Koch, G Linear neutralızıng epıtopes on the peplomer protein of coronaviruses Adv Exp Med Biol 1990,276 181-188

70 Pulford, D J, Britton, P Expression and cellular localısation of porcine transmissible gastroenteritıs virus $\mathrm{N}$ and M proteins by recombinant vaccinıa viruses Vir Res 1990, 18 203-218

71 Reddy, P S, Nagy, E, Derbishire, J B Restriction endonuclease analysis and molecular cloning of porcine adenovirus type 3 Intervirology 1993, 36 161-168

72 Rısco, C, Anton, I M, Suñe, C, Pedregosa, A M, Martın-Alonso, J M, Parra, F, Carrascosa, J L, Enjuanes, $\mathrm{L}$ The membrane protein of transmissible gastroenteritis coronavirus exposes the carboxy-terminal region on the external surface of the virion 1994 Submitted

73 Routledge, E, Stauber, R, Pfleiderer, M, Siddell, S G Analysis of murine coronavirus surface glycoprotein functions by using monoclonal antibodies J Virol 1991, 65 254-262

74 Saif, L J, Wesley, R D Transmissıble gastroenterıtıs In Leman A D, Straw, B , Mengelıng, W L, D' Allaire, S, Taylor, D J, (eds), Diseases of swine Iowa State University Press, Ames, Iowa 1992, pp 362-386

75 Sanchez, C M , Jimenez, G, Laviada, M D , Correa, I, Suñe, C , Bullıdo, M J , Gebauer, F, Smerdou, $\mathrm{C}$, Callebaut, P, Escribano, J M , Enjuanes, L Antıgenic homology among coronaviruses related to transmissible gastroenteritıs virus Virology 1990, 174 410-417

76 Sanchez, C M, Torres, J M, Suñe, C, Smerdou, C, Graham, F L, Enjuanes, L Transmissible gastroenteritıs coronavirus spike proteın expressed by adenovirus vectors elicited virus neutralızıng antibodies in hamsters 1994 Submitted

77 Sasakı, N , Hayashı, M , Aoyama, S, Yamashıta, T, Miyoshı, I , Kasaı, N, Namıoka, S Transgenıc mice with antısense RNA against the nucleocapsıd protein mRNA of mouse hepatitıs virus $\mathrm{J}$ Vet Med Sc1 1993, 55 549-554

78 Scott, F W, Corap1, W V, Olsen, C W Evaluation of the safety and efficacy of Primucell-FIPR vaccine Feline Health Topics 1992, 7 6-8

79 Sethna, P B , Hung, S -L, Brıan, D A Coronavırus subgenomic minus-strand RNAs and the potentıal for mRNA replicons Proc Natl Acad Sci USA 1989, 86 5626-5630

80 Smerdou, C, Anton, I M, Plana, J, Curtiss, R, Enjuanes, L Expression of a contınuos epitope from Transmissible gastroenteritis coronavirus $\mathrm{S}$ protein fused to $E$ coll heat-labile toxin $\mathrm{B}$ subunit in attenuated Salmonella for oral immunization 1994 Submitted

81 Smith-Klıne, B Unıversal coronavirus vaccine, spıke proteın clonıng and expression for use as a recombinant vaccine Vaccine 1994, 12671

82 Spaan, W, Cavanagh, D , Horzınek, M C Coronavıruses structure and genome expression J Gen Virol 1988, 69 2939-2952

83 Spaan, W, Cavanagh, D , Horzınek, M C Coronavıruses In van Regenmortel M H V, Neurath, A R, (eds ), Immunochemistry of viruses II The basis for serodiagnosis and vaccines Elsevier, 1990, pp 359-379

84 Stohlman, S A, Bergmann, C, Cua, D, Wege, H Location of antibody epitopes withın the mouse hepatitis virus nucleocapsid protein Virology 1994, 202 146-153

85 Stohlman, S A, Kyuwa, S, Cohen, M, Bergmann, C, Polo, J M, Yeh, J, Anthony, R, Keck, J G Mouse hepatitıs virus nucleocapsid protein-specific cytotoxic $T$ lymphocytes are $L^{d}$ restricted and specific for the carboxy termınus Virology 1992, 189 217-224

86 Sturman, L, Holmes, K, V The novel proteins of coronaviruses Trends B1ochem Sc1 1985, 10 17-20

87 Talbot, P J, Dionne, G, Lacroix, M Vaccination against lethal coronavirus-induced encephalitis with a synthetıc decapeptide homologous to a domain in the predicted peplomer stalk J Virol 1988, 62 3032-3036

88 Talbot, P J, Salmı, A A, Knobler, R L, Buchmeır, M J Topographical mapping of epitopes on the glycoprotein of murine hepatitıs virus-4 (Strain JHM) correlation with biological activities Virology $1984,132250-260$

89 To, L T, Bernard, S , Lantier, I Fixed-cell ımmunoperoxıdase technıque for the study of surface antigens induced by the coronavirus of transmissible gastroenteritis (TGEV) Vet Microbiol 1991, 29 361-368

90 Tooze, S A, Stanley, K K Identification of two epitopes in the carboxyterminal 15 amino acids of the E1 glycoprotein of mouse hepatitıs virus A59 by using hybrid proteins J Virol 1986, 60 928-934

91 Torres, J M, Escribano, J A M, Enjuanes, L Induction of lactogenic immunity to transmissible gastroenteritıs coronavirus with recombinant Adenovirus 5 expressing TGEV spike protein 1995 Submitted

92 Tung, F Y T, Abraham, S, Sethna, M, Hung, S L, Sethna, P, Hogue, B G, Brian, D A The 9-kDa hydrophobic protein encoded at the $3^{\prime}$ end of the porcine transmissible gastroenteritis coronavirus genome is membrane-associated Virology 1992, 186 676-683 
93 van der Most, R G, Bredenbeek, P J A domain at the $3^{\prime}$ end of the polymerase gene is essential for encapsidation of coronavirus defective interfering RNAs J Virol 1991, 65 3219-3226

94 van der Most, R G, Bredenbeek, P J, Spaan, W J M A domain at the $3^{\prime}$ end of the polymerase gene is essential for encapsidation of coronavirus defectıve interfering RNAs J Virol 1991, 65 3219-3226

95 van der Most, R G, De Groot, R J, Spaan, W J M Subgenomıc RNA synthesıs directed by a synthetıc defectıve interferıng RNA of mouse Hepatitis virus a study of Coronavirus transcription initiation J Virol 1994, 68 3656-3666

96 van der Most, R G, Heınen, L, Spaan, W J M, Degroot, R J Homologous RNA recombination allows efficient introduction of site-specific mutations into the genome of coronavirus MHV-A59 via synthetic coreplicatıng RNAs Nuc Ac Res 1992, 20 3375-3381

97 Vennema, H, De Groot, R J, Harbour, D A, Horzınek, M C, Spaan, W J M Primary structure of the membrane and nucleocapsid protein genes of Feline infectious peritonitıs virus and immunogenicity of recombinant vaccinıa viruses in kittens Virology 1991, 181 327-335

98 Vennema, H, DeGroot, R J, Harbour, D A , Dalderup, M , Gruffydd-Jones, T, Horzınek, M C, Spaan, W J M Early death after felıne infectious peritonitıs challenge due to recombinant vaccinia virus immunization J Virol 1990, 64 1407-1409

99 Wang, F I, Flemıng, J O, Lal, M M C Sequence analysıs of the spıke proteın gene of murıne coronavirus variants Study of genetic sites affectıng neuropathogenicity Virology 1992, 186 742-749

100 Wege, H, Schlıephake, A, Korner, H, Flory, E, Wege, H Coronavirus induced encephalomyelitıs an immunodominant CD4+-T cell site on the nucleocapsid protein contributes to protection Adv Exp Med Biol 1994, 342 413-418

101 Welch, S K W, Saif, L J Monoclonal antibodies to a virulent strain of transmissible gastroenteritıs virus comparıson of reactivity with virulent and attenuated virus Arch Virol 1988, 101 221-235

102 Wesselıng, J G, Godeke, G J Mouse hepatitıs virus spıke and nucleocapsid proteıns expressed by adenovirus vector protect mice against a lethal infection J Gen Virol 1993, 74 2061-2069

103 Williamson, J S P, Stohlman, S A Effective clearance of mouse hepatitis virus from the central nervous system requires both CD4+ and CD8+ T cells J Virol 1990, 64 4589-4592

104 Woods, R D, Wesley, R D, Kapke, P A Complement-dependent neutralization of transmissible gastroenteritıs virus by monoclonal antibodies Adv Exp Med Biol 1987, 218 493-500

105 Yoden, S, Kıkuchı, T, Siddell, S G, Taguchı, F Expression of the peplomer glycoprotein of murine coronavirus JHM using a baculovirus vector Virology 1989, 173 615-623

106 Yoo, D, Parker, M D, Babıuk, L A The S2 subunit of the spıke glycoprotein of bovine coronavirus mediates membrane fusion in insect cells Virology 1991, 180 395-399

107 Yoo, D, Parker, M D, Song, J, Graham, F L, Deregt, D, Babiuk, L A Structural analysis of the conformational domains involved in neutralızation of Bovine Coronavirus using deletion mutants of the spike glycoprotein S1 subunit expressed by recombinant baculoviruses Virology 1991, 18391 - 98

108 Yoo, D W, Graham, F L, Prevec, L, Parker, M D, Benko, M, Zamb, T, Babiuk, L A Synthesis and processing of the haemagglutının-esterase glycoprotein of bovine coronavirus encoded in the E3 region of adenovirus J Gen Virol 1992, 73 2591-2600 